\title{
HUBUNGAN LINGKUNGAN BELAJAR DAN MOTIVASI BELAJAR DENGAN MINAT BELAJAR MAHASISWA SEMESTER III PROGRAM STUDI DIPLOMA III KEBIDANAN STIKES PRIMA NUSANTARA BUKITTINGGI
}

\author{
Nova Asvio \\ Mahasiswa Program Pascasarjana STAIN Batusangkar \\ Program Studi Manajemen Pendidikan Islam \\ email: novawawanajeng@gmail.com
}

\begin{abstract}
This research was started from the students' interest in STIKes Prima Nusantara Bukittinggi Diploma III of midwifery in the academic year 2011 on learning were high. There were 91,9\% of students got achievement index $>2,75$. This research was aimed at finding the correlation of learning environment, students' learning motivation and students' learning interest. This research belongs to survey analitic by using cross sectional approach. The samples were 96 students and the questionnaire was used as instrument. The data analysis were done by applying statistical test chi square $\left(x^{2}\right)$. The findings revealed that there were meaningful correlations of learning environment, students' learning motivation and students' learning interest.
\end{abstract}

Keywords: Learning Environment, Students' Learning Motivation and Students' Learning Interest

\section{PENDAHULUAN}

Penelitian ini bertujuan untuk mengetahui hubungan lingkungan belajar dan motivasi belajar dengan minat belajar mahasiswa semester IV Program Studi D III Kebidanan STIKes Prima Nusantara Bukittinggi Tahun 2011. Survei awal menunjukkan bahwa dari 98 orang mahasiswa semester IV Program Studi D III Kebidanan STIKes Prima Nusantara Bukittinggi yang memiliki IPK < 2,75 berjumlah 12 orang, hanya $8,1 \%$ yang memiliki IPK di bawah standar $(2,75)$. Hasil wawancara 12 orang mahasiswa menunjukkan bahwa 7 orang di antaranya memilih kuliah di D III Kebidanan didasarkan atas minatnya sendiri, 5 orang dari 12 orang mahasiswa tersebut memilih kuliah di D III Kebidanan bukan atas kemauan sendiri melainkan kemauan orang-orang terdekat seperti orang tua dan saudara.

Banyaknya mahasiswa yang memiliki IPK > 2,75 dan juga berminat kuliah di D III STIKes Prima Nusantara ini tentunya didukung oleh faktor eksternal dan faktor internal. Faktor eksternal yaitu lingkungan, seperti jauh dari jalan raya, 
kelas yang nyaman untuk tempat belajar dan lingkungan sekitar kampus yang dikelilingi warung internet. Faktor internal yaitu motivasi dari mahasiswa itu sendiri, yang mana dari faktor-faktor ini menimbulkan minat belajar mereka.

Minat dan bakat sangat mempengaruhi kualitas pencapaian hasil belajar mahasiswa. Seseorang yang menaruh minat besar terhadap ilmu kebidanan akan memusatkan perhatiannya lebih banyak daripada siswa lainnya yang kurang berminat terhadap ilmu kebidanan ini (Syah, 2010).

Dalam proses pembelajaran harus melibatkan peran lingkungan sosial. Anak akan lebih mempelajari pengetahuan logika dan sosial dari temannya sendiri. Melalui pergaulan dan hubungan, sosial anak akan belajar efektif dibandingkan dengan belajar yang menjauhkan dari hubungan sosial. Oleh karena itu melalui hubungan sosial itulah anak berinteraksi dan berkomunikasi, berbagi pengalaman dan lain sebagainya. Yang memungkinkan mereka berkembang secara wajar (Sanjaya, 2008).

Aspek psikologis berupa motivasi juga mempengaruhi minat belajar mahasiswa, karena organisme baik manusia ataupun hewan yang mendorongnya untuk berbuat sesuatu adalah motivasi yang dimilikinya (Syah, 2010). Oleh karena itu, penelitian ini dilakukan untuk mengetahui hubungan lingkungan belajar dan motivasi belajar dengan minat belajar mahasiswa semester IV Program Studi D III Kebidanan STIKes Prima Nusantara Bukittinggi tahun 2011.

\section{MINAT BELAJAR}

\section{Pengertian Minat}

Menurut Slameto (2003) minat adalah suatu rasa lebih suka dan rasa keterikatan pada suatu hal atau aktivitas, tanpa ada yang menyuruh. Suatu minat diekspresikan melalui suatu pernyataan yang menunjukkan bahwa anak didik lebih menyukai suatu hal daripada hal lainnya, dapat pula dimanifestasikan melalui partisipasi dalam suatu aktivitas. Anak didik memiliki minat terhadap tertentu cenderung untuk memberikan perhatian yang lebih besar terhadap subjek tersebut (Djamarah, 2008: 191). Slameto (2003) menyimpulkan bahwa minat tidak dibawa sejak lahir, melainkan diperoleh kemudian. Dengan kata lain, Slameto (2003) ingin mengatakan bahwa minat dapat ditumbuhkan dan dikembangkan pada diri seorang anak didik.

Minat adalah suatu penerimaan akan suatu hubungan antara diri sendiri dengan sesuatu di luar diri. Anak didik cenderung malas belajar untuk mempelajari mata pelajaran yang tidak disukai. Anak didik pasrah pada nasib dengan nilai apa adanya 
(Djamarah, 2008: 191-192). Minat adalah kecenderungan dan kegairahan yang tinggi atau keinginan yang besar terhadap sesuatu yang ingin dicapai (Syah, 2010: 152).

Dari beberapa pendapat para ahli di atas dapat disimpulkan bahwa seorang mahasiswa harus memiliki minat belajar yang tinggi agar dapat menghasilkan prestasi yang tinggi, sebaliknya minat belajar yang rendah akan menghasilkan prestasi belajar yang rendah.

\section{Pengertian Belajar}

Belajar adalah tindakan dan perilaku siswa yang kompleks. Sebagai tindakan, maka belajar hanya dialami oleh siswa sendiri (Dimyati, 2006: 7). Kemudian Sardiman (2011: 20) mengemukakan pendapat dari Cronbach yang mengatakan "learning is shown by a behavior as a result of experience". Artinya "Belajar adalah terlihat pada perilaku sebagai hasil dari pengalaman".

Belajar boleh dikatakan juga sebagai suatu proses interaksi antara diri manusia dengan lingkungannya, yang mungkin berwujud pribadi, fakta, konsep ataupun teori. Orang yang tadinya tidak tahu setelah belajar menjadi tahu. Jelasnya proses belajar senantiasa merupakan perubahan tingkah laku, dan terjadi karena hasil pengalaman. Oleh karena itu, dapat dikatakan proses belajar, apabila seseorang menunjukkan "tingkah laku yang berbeda" (Sardiman, 2011: 22-23).

Belajar dapat dipahami sebagai tahapan perubahan seluruh tingkah laku individu yang relatif menetap sebagai hasil pengalaman dan interaksi dengan lingkungan yang melibatkan proses kognitif (Syah, 2010: 68). Belajar adalah suatu kegiatan yang dilakukan dengan melibatkan dua unsur yaitu jiwa dan raga. Gerak raga yang ditunjukkan harus sejalan dengan proses jiwa untuk mendapatkan perubahan. Djamarah (2008: 13) menyimpulkan bahwa belajar adalah serangkaian kegiatan jiwa dan raga untuk memperoleh suatu perubahan tingkah laku sebagai hasil dari pengalaman individu dalam interaksi dengan lingkungannya yang menyangkut kognitif, afektif, dan psikomotor.

Dari beberapa pengertian belajar yang telah dikemukakan oleh para ahli tersebut, dapat disimpulkan bahwa belajar adalah suatu perubahan tingkah laku individu dari hasil pengalaman dan latihan. Perubahan tingkah laku tersebut, baik dalam aspek pengetahuan (kognitif), keterampilan (psikomotor), maupun sikapnya (afektif).

Dari pengertian minat dan pengertian belajar seperti yang telah diuraikan di atas, maka dapat disimpulkan bahwa minat belajar adalah sesuatu keinginan atau kemauan yang disertai perhatian dan keaktifan 
yang disengaja yang akhirnya melahirkan perubahan tingkah laku, baik berupa pengetahuan, sikap dan keterampilan.

\section{LINGKUNGAN BELAJAR}

Lingkungan merupakan bagian dari kehidupan anak didik. Di dalam lingkunganlah seorang anak didik saling berinteraksi antara lingkungan biotik dan abiotik. Selama hidup, anak didik tidak bisa menghindarkan diri dari dua aspek yang berpengaruh signifikan terhadap belajar anak didik, yaitu (Djamarah, 2008):

1. Lingkungan alami

Lingkungan alami atau lingkungan hidup adalah lingkungan tempat tinggal anak didik, hidup dan berusaha di dalamnya.

2. Lingkungan sosial budaya

Lingkungan sosial merupakan suatu hidup dalam kebersamaan dan saling membutuhkan antara satu dengan lainnya.

Faktor eksternal belajar siswa terdiri dari dua macam, antara lain (Syah, 2010: 154-156):

\section{Lingkungan Sosial}

Lingkungan sosial sekolah seperti para guru, para staf administrasi, dan temanteman sekelas dapat mempengaruhi semangat belajar seorang siswa. Selanjutnya yang termasuk lingkungan sosial siswa adalah masyarakat dan tetangga juga teman-teman sepermainan di sekitar perkampungan siswa tersebut.

2. Lingkungan Nonsosial

Lingkungan nonsosial adalah gedung sekolah dan letaknya, rumah tempat tinggal keluarga siswa dan letaknya, alatalat belajar, keadaan cuaca dan waktu belajar yang digunakan siswa.

Setiap siswa berada dalam lingkungan sosial siswa di sekolah. Ia memiliki kedudukan dan peranan yang diakui oleh sesama. Jika seorang siswa diterima, maka ia akan mudah menyesuaikan diri dan segera dapat belajar. Sebaliknya, jika ia tertolak, maka ia akan merasa tertekan. Pengaruh lingkungan sosial tersebut berupa hal-hal berikut (Dimyati, 2006: 252-253):

1. Pengaruh kejiwaan yang bersifat menerima atau menolak siswa, yang akan berakibat memperkuat atau memperlemah konsentrasi belajar;

2. Lingkungan sosial mewujud dalam suasana akrab, gembira, rukun, dan damai; sebaliknya, mewujud dalam suasana perselisihan, bersaing, salahmenyalahkan, dan cerai-berai. Suasana kejiwaan tersebut berpengaruh pada 
semangat dan proses belajar. Suasana kejiwaan dalam lingkungan sosial siswa dapat menghambat proses belajar; dan

3. Lingkungan sosial siswa di sekolah atau juga di kelas dapat berpengaruh pada semangat belajar siswa.

\section{MOTIVASI}

Kata "motif", diartikan sebagai daya upaya yang mendorong seseorang untuk melakukan sesuatu. Motif dapat dikatakan sebagai daya penggerak dari dalam dan di dalam subjek untuk melakukan aktivitasaktivitas tertentu demi mencapai suatu tujuan. Berawal dari kata "motif" itu, maka motivasi dapat diartikan sebagai daya penggerak yang telah menjadi aktif. Motif menjadi aktif pada saat-saat tertentu, terutama bila kebutuhan untuk mencapai tujuan sangat dirasakan atau mendesak (Sardiman, 2011: 73). Motivasi adalah perubahan energi seseorang yang ditandai dengan munculnya "feeling" dan didahului dengan tanggapan terhadap adanya tujuan (Sardiman, 2011:73). Motivasi adalah suatu perubahan energi didalam pribadi seseorang yang ditandai dengan timbulnya efeltif (perasaan) dan reaksi untuk mencapai tujuan tertentu (Djamarah, 2008: 95).

Motivasi terdiri dari dua bagian, yaitu (Djamarah, 2008: 149-152):
1. Motivasi intrinsik

Motivasi intrinsik adalah motif-motif yang menjadi aktif atau fungsinya tidak perlu dirangsang dari luar, karena dalam setiap diri individu sudah ada dorongan untuk melakukan sesuatu.

2. Motivasi ekstrensik

Motivasi ekstrinsik adalah kebalikan dari motivasi intrinsik. Motivasi ekstrinsik adalah motif-motif yang aktif dan berfungsi karena adanya perangsang atau pengaruh dari luar.

Motivasi dapat juga dikatakan serangkaian usaha untuk menyediakan kondisi-kondisi tertentu, sehingga seseorang mau dan ingin melakukan sesuatu, dan bila ia tidak suka, maka akan berusaha untuk meniadakan atau mengelakkan perasaan tidak suka itu. Jadi motivasi dapat dirangsang oleh faktor dari luar tetapi motivasi itu tumbuh di dalam diri seseorang.

\section{KERANGKA TEORI}

Menyadari pentingnya mengetahui minat belajar mahasiswa dalam meningkatkan pengetahuan maka kerangka teori dalam penelitian ini adalah sebagai berikut: 


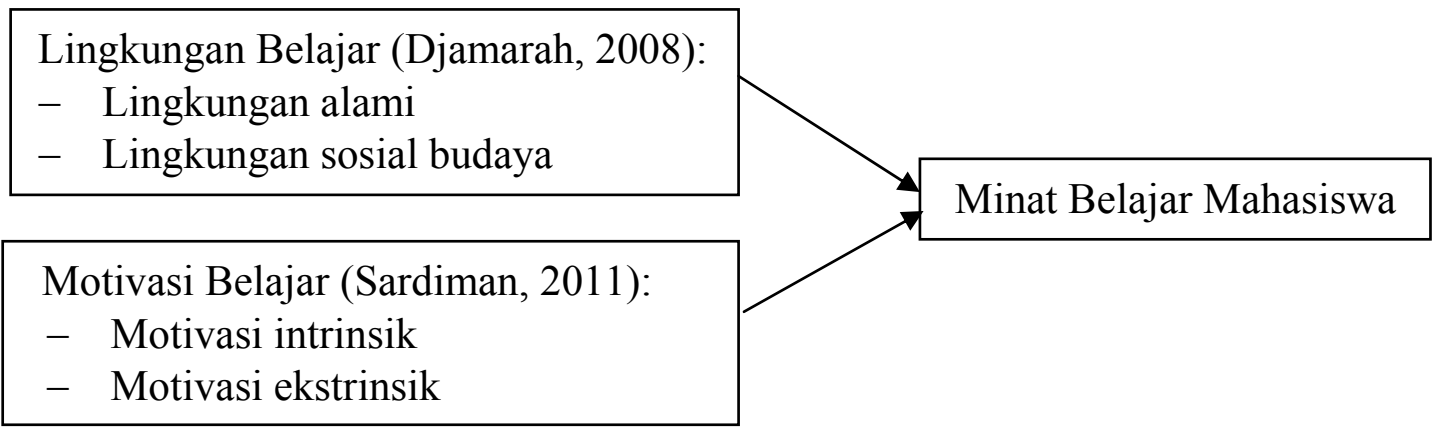

Gambar 1. Kerangka Teori

\section{METODE PENELITIAN}

Desain penelitian ini adalah survey analitic untuk mengetahui hubungan lingkungan belajar dan motivasi belajar dengan minat belajar mahasiswa semester III Program Studi D III Kebidanan STIKes Prima Nusantara Bukittinggi tahun 2011 (Notoatmodjo, 2005).

Secara garis besar survey analitic dibedakan dalam 3 pendekatan (jenis). Pada penelitian ini peneliti menggunakan pendekatan cross sectional (Hidayat, 2007) yaitu jenis penelitian untuk menekankan waktu pengukuran atau observasi data variabel independen dan dependen dinilai pada satu saat, jadi tidak ada tindak lanjut terhadap hasil penelitian (Nursalam, 2009).

Penelitian ini telah dilaksanakan di STIKes Prima Nusantara Bukittinggi dari bulan Maret sampai dengan Juli 2011. Adapun yang menjadi subjek penelitian ini adalah Mahasiswi semester III Program Studi D III Kebidanan STIKes Prima
Nusantara yang berjumlah 96 orang. Sampel dalam penelitian ini adalah seluruh jumlah populasi yang berjumlah 96 orang (seluruh mahasiswa semester III Program Studi D III Kebidanan STIKes Prima Nusantara Bukittinggi).

Jenis data yang digunakan pada penelitian ini adalah data primer untuk mengetahui hubungan lingkungan belajar dan motivasi belajar dengan minat belajar mahasiswa semester III Program Studi D III Kebidanan STIKes Prima Nusantara Bukittinggi dengan menggunakan angket sebanyak 30 soal. Data dikumpulkan dengan terlebih dahulu mengajukan permohonan izin pelaksanaan penelitian pada institusi Pendidikan Program Studi D IV Bidan Pendidik STIKes Prima Nusantara Bukittinggi, dan meminta izin melakukan penelitian pada Direktur STIKes Prima Nusantara Bukittinggi. Setelah mendapat izin, peneliti mengumpulkan semua responden dan penelitian dilakukan dengan pengumpulan data, terlebih 
dahulu menjelaskan kepada responden tentang tujuan dan manfaat serta prosedur pelaksanaan penelitian, meminta responden menandatangani informed consent yang disediakan peneliti serta membagikan kuesioner kepada masing-masing responden.

Data yang telah terkumpul diolah dengan cara manual dengan langkahlangkah sebagai berikut (Budiarto, 2002: 29-32):

\section{Editing}

Dilakukan pengecekan kelengkapan identitas responden dan pengecekan kelengkapan data yang telah diisi responden.

\section{Coding}

Memberi coding terhadap bagian-bagian yang perlu diberi kode, dengan cara sebagai berikut (Arikunto, 2002: 210):

- 1 untuk jawaban yang tepat

- 0 untuk jawaban yang salah

\section{Tabulating}

Data yang diperoleh dari hasil kuesioner yang telah diolah dan dipindahkan ke dalam tabel untuk masing-masing tabel dan untuk masing-masing variabel.

Kemudian data dianalisa dengan komputerisasi dengan langkah-langkah sebagai berikut (Hastono, 2001: 61):

\section{Univariat}

Analisis ini digunakan untuk mendiskripsikan karakteristik masingmasing variabel yang diteliti. Dimana data yang bersifat kategorik digunakan analisis univariat untuk mengetahui distribusi frekuensi.

\section{Bivariat}

Analisis ini digunakan untuk menerangkan adanya hubungan antara dua variabel yaitu hubungan lingkungan belajar dengan minat belajar dan hubungan motivasi belajar dengan minat belajar. Dalam menganalisis data secara bivariat, pengujian data dianalisa dengan komputerisasi program SPSS dan menggunakan uji statistik chi square $\left(\chi^{2}\right)$ dengan taraf signifikasi $95 \%$ $(\alpha=0,05)$. Pedoman dalam menerima hipotesis: apabila nilai $\mathrm{F}_{\text {hitung }}>\mathrm{F}_{\text {tabel }}$ atau nilai probabilitas $\mathrm{p} \leq \alpha$ maka hipotesis penelitian diterima $\left(\mathrm{H}_{0}\right.$ ditolak) dan data akan disajikan dalam bentuk tabel.

Menyadari pentingnya mengetahui minat belajar mahasiswa dalam meningkatkan pengetahuan maka kerangka konsep berjudul "Hubungan Lingkungan Belajar dan Motivasi Belajar dengan Minat Belajar Mahasiswa Semester III Program Studi D III Kebidanan STIKes Prima Nusantara Bukittinggi Tahun 2011" adalah seperti di bawah ini : 
Variabel Independen

Variabel Dependen

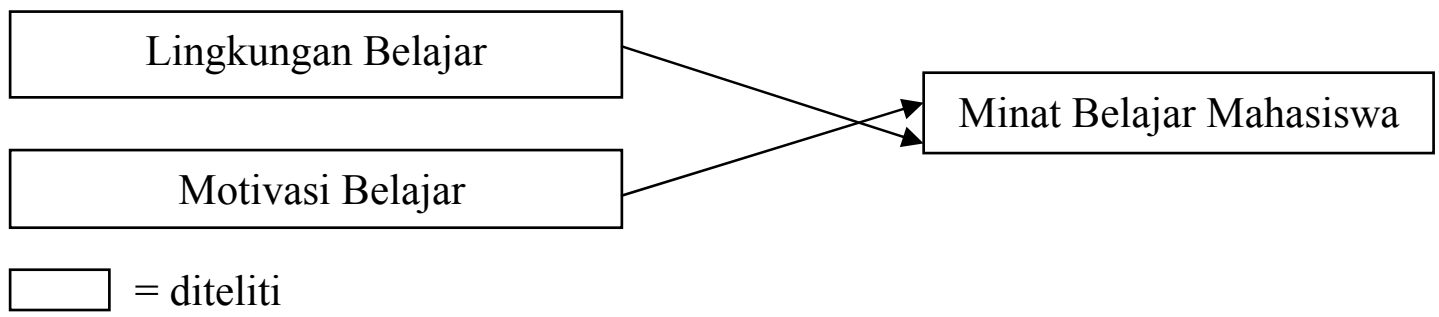

Gambar 2. Kerangka Konsep

\section{HIPOTESA}

1. Ada hubungan yang bermakna antara lingkungan belajar dengan minat belajar mahasiswa.

2. Ada hubungan yang bermakna antara motivasi belajar dengan minat belajar mahasiswa.

\section{HASIL PENELITIAN DAN PEMBAHASAN}

\section{Analisa Univariat}

\section{a. Minat Belajar}

Berdasarkan hasil penelitian yang telah dilakukan terhadap 96 orang mahasiswa, diketahui bahwa 50 orang mahasiswa $(52,1 \%)$ memiliki minat belajar tinggi dan 46 orang $(47,9 \%)$ memiliki minat belajar rendah. Hasil penelitian ini didukung oleh temuan Fauza (2009) yang menunjukkan bahwa mahasiswa memiliki minat belajar kurang baik dengan jumlah 33 orang $(47,1 \%)$ dari 70 orang mahasiswa.
Menurut asumsi peneliti, mahasiswa yang memiliki minat tinggi disebabkan karena adanya perhatian terhadap aktifitas belajar, yang berawal dari adanya bakat terhadap materi pelajaran tersebut. Hal ini berawal dari adanya cita-cita untuk menjadi bidan, yang kemudian melahirkan kesukaan kuliah di kebidanan dan pada akhirnya dapat memberikan perhatian terhadap proses belajar mengajar dan materi perkuliahan yang diterima setiap hari.

Bagi mahasiswa yang memiliki minat belajar rendah disebabkan karena menjadi bidan bukanlah cita-cita mereka, namun keputusan untuk kuliah di kebidanan lahir karena orang-orang terdekat yang seorang bidan. Pada akhirnya kondisi ini menyebabkan mahasiswa yang bersangkutan kurang perhatian terhadap materi pembelajaran yang diberikan dosen, hal ini menunjukkan kurangnya minat mahasiswa terhadap pelajaran tersebut. 
Oleh sebab itu perlu kiranya dibangkitkan minat belajar mahasiswa tersebut agar dapat mencapai prestasi belajar yang baik. Usaha yang dapat dilakukan berupa membangkitkan rasa kebutuhan terhadap pelajaran, menghubungkan bahan pelajaran yang diberikan dengan persoalan pengalaman yang dimiliki, memberikan kesempatan kepada mahasiswa untuk mendapatkan hasil belajar yang baik dengan menyediakan lingkungan belajar yang aman dan nyaman, menggunakan berbagai macam bentuk dan teknik mengajar dalam konteks perbedaan individual mahasiswa.

\section{b. Lingkungan Belajar}

Berdasarkan hasil penelitian yang telah dilakukan terhadap 96 orang mahasiswa, diketahui bahwa 58,3\% mahasiswa menyatakan lingkungan belajar baik dan 41,7 \% mahasiswa menyatakan lingkungan belajar kurang baik. Hasil penelitian ini didukung oleh temuan Fauza (2009) yang menunjukkan bahwa mahasiswa memiliki lingkungan belajar baik dan kurang baik sama besar dengan jumlah 35 orang $(50 \%)$.

Menurut asumsi peneliti, mahasiswa yang menyatakan faktor lingkungan belajar pada kategori baik disebabkan karena merasa nyaman untuk belajar di ruang kelas, nyaman dengan lingkungan belajar yang ada sekarang. Lingkungan belajar dapat memudahkan dalam melaksanakan setiap tugas dosen, dan memberi motivasi dalam belajar.

Hal ini dapat disebabkan karena lingkungan kampus yang jauh dari jalan raya sehingga tidak terganggu oleh kebisingan, kelas yang nyaman untuk tempat belajar dan lingkungan sekitar kampus yang dikelilingi sarana dan prasarana yang mencukupi kebutuhan mahasiswa. Seperti fasilitas internet yang sangat diperlukan untuk mencari datadata atau jurnal sehubungan dengan masalah kebidanan, fasilitas foto copy dan rental untuk menyelesaikan tugastugas yang diberikan dosen, serta ruang labor yang mencukupi untuk kapasitas seluruh mahasiswa.

\section{c. Motivasi belajar}

Berdasarkan hasil penelitian yang dilakukan menunjukkan bahwa terdapat $67,7 \%$ mahasiswa memiliki motivasi belajar tinggi dan 32,2\% mahasiswa memiliki motivasi belajar rendah. Hasil penelitian ini didukung oleh temuan Fauza (2009) yang menunjukkan bahwa mahasiswa memiliki motivasi belajar kurang baik sebanyak 29 orang $(41,4 \%)$. 
Menurut asumsi peneliti, banyak mahasiswa yang memiliki motivasi belajar tinggi sehubungan dengan motivasi yang datang dari dalam dan luar diri mahasiswa itu sendiri. Motivasi dari dalam seperti adanya keinginan untuk menjadi mahasiswa yang berprestasi dan menjadi bidan professional. Sedangkan motivasi dari luar berupa nasehat yang diberikan oleh dosen dan orang tua, serta adanya hadiah dan pujian dari orang sekitar.

Bagi mahasiswa yang memiliki motivasi belajar rendah disebabkan karena mereka kurang memiliki keinginan untuk mendapat pujian dari dosen maupun teman-teman, kurangnya keinginan untuk mendapatkan hadiah. Dalam hal ini, motivasi yang datang dari anak itu sendiri lebih dominan untuk meningkatkan motivasi belajar mahasiswa, seperti memiliki prilaku dan karakter pintar, berkualitas, mempunyai identitas, dan bisa mengatur diri sendiri.

Oleh sebab itu, sangat diperlukan sekali upaya-upaya yang dilakukan oleh para dosen ataupun orang tua untuk meningkatkan motivasi belajar mahasiswa. Karena dalam hal ini mahasiswa juga memerlukan pujian maupun hadiah, maka untuk meningkatkan motivasi belajar dosen dapat melakukan variasi metode pembelajaran yang dapat menyenangkan mahasiswa, adanya relevansi kurikulum dengan kebutuhan dan minat mahasiswa. Kemudian bagi orang tua sangat diperlukan peranannya dalam membantu memecahkan masalah pribadi mahasiswa yang bersangkutan, baik masalah dengan orang tua mereka sendiri, masalah dengan teman maupun masalah dengan lingkungan sekitar.

\section{Analisa Bivariat}

\section{a. Hubungan Lingkungan Belajar dengan Minat Belajar}

Berdasarkan hasil penelitian diketahui bahwa dari 56 orang mahasiswa yang menyatakan lingkungan belajar baik, terdapat 36 orang $(64,3 \%)$ memiliki minat belajar tinggi, dan dari 40 mahasiswa yang menyatakan lingkungan belajar kurang, hanya terdapat 14 orang $(35,0 \%)$ memiliki minat belajar tinggi. Setelah dilakukan uji statistik diketahui bahwa terdapat hubungan yang bermakna antara lingkungan belajar dengan minat belajar mahasiswa semester III Program Studi D III Kebidanan STIKes Prima Nusantara Bukittinggi ahun 2011 (Hipotesa diterima), dimana nilai $\mathrm{p}<0,05(\mathrm{p}=0,009)$. Hasil penelitian ini sesuai dengan teori yang menyatakan 
bahwa salah satu cara yang dapat dilakukan untuk membangkitkan minat belajar mahasiswa, yaitu memberikan kesempatan kepada mahasiswa untuk mendapatkan hasil belajar yang baik dengan menyediakan lingkungan belajar yang aman dan nyaman (Djamarah, 2008: 167).

Dalam proses pembelajaran harus melibatkan peran lingkungan sosial. Anak akan lebih mempelajari pengetahuan logika dan sosial dari temannya sendiri. Melalui pergaulan dan hubungan, sosial anak akan belajar efektif dibandingkan dengan belajar yang menjauhkan dari hubungan sosial. Oleh karena itu melalui hubungan sosial itulah anak berinteraksi dan berkomunikasi, berbagi pengalaman dan lain sebagainya. Yang memungkinkan mereka berkembang secara wajar (Sanjaya, 2008 : 106).

Hasil penelitian ini didukung oleh temuan Fauza (2008) yang menunjukkan dari 35 orang mahasiswa yang memiliki lingkungan belajar baik mayoritas memiliki minat belajar baik yaitu 26 orang $(74,3 \%)$ dengan nilai signifikan 0,001<0,05. Ini berarti terdapat hubungan yang signifikan antara lingkungan belajar dengan minat belajar mahasiswa.
Menurut asumsi peneliti, lingkungan belajar yang baik dapat mendorong untuk lahirnya minat yang tinggi. Karena lingkungan tempat belajar, gedung kampus, kualitas dosen juga akan mempengaruhi anak dalam proses belajar mengajar. Dengan adanya lingkungan belajar yang mendukung, akan dapat mendorong timbulnya bakat dan minat mahasiswa terhadap materi yang diajarkan, sehingga pada akhirnya dapat mencapai prestasi yang tinggi.

Bagi mahasiswa yang menyatakan lingkungan belajar pada kategori baik namun memiliki minat belajar rendah, disebabkan karena adanya faktor internal yang telah ada sejak dari awal, seperti mahasiswa yang kuliah di kebidanan karena tertarik terhadap orang dekat yang juga bidan, ataupun karena ada yang menyuruh untuk kuliah di kebidanan. Begitu juga dengan adanya intelengensia yang kurang, dan bakat yang kurang terhadap setiap materi pelajaran, menyebabkan mahasiswa kurang berminat untuk mengikuti proses pembelajaran.

\section{b. Hubungan Motivasi Belajar dengan Minat Belajar}

Berdasarkan hasil penelitian diketahui bahwa dari 65 mahasiswa yang memiliki motivasi belajar tinggi, terdapat 41 orang 
$(63,1 \%)$ memiliki minat belajar tinggi, dan dari 31 mahasiswa yang memiliki motivasi belajar rendah, hanya terdapat 9 orang $(29,0 \%)$ memiliki minat belajar tinggi. Setelah dilakukan uji statistik diketahui bahwa terdapat hubungan yang bermakna antara motivasi belajar dengan minat belajar mahasiswa semester III Program Studi D III Kebidanan STIKes Prima Nusantara Bukittinggi tahun 2011 (Hipotesa diterima), dimana nilai $p<0,05(p=0,004)$. Hasil penelitian ini sesuai dengan teori yang menyatakan bahwa Motivasi dapat berfungsi sebagai pendorong usaha dan pencapaian prestasi. Seseorang melakukan suatu usaha karena adanya motivasi. Adanya motivasi yang baik dalam belajar akan menunjukkan hasil yang baik. Dengan kata lain, dengan adanya usaha yang tekun dan terutama didasari adanya motivasi, maka seseorang yang belajar itu akan dapat melahirkan prestasi baik. Intensitas motivasi seorang mahasiswa akan sangat menentukan tingkat pencapaian prestasi belajar (Djamarah, 2008: 86).

Hasil penelitian ini didukung oleh temuan Fauza (2009) yang mengungkapkan bahwa dari 41 orang mahasiswa yang memiliki motivasi belajar baik sebagian besar memiliki minat belajar baik yaitu 28 orang $(68,3$ $\%$ ) dengan nilai signifikan 0,005 $<0,05$. Ini berarti terdapat hubungan yang signifikan antara motivasi belajar dengan minat belajar mahasiswa.

Menurut asumsi peneliti, mahasiswa yang memiliki motivasi tinggi akan memiliki minat yang juga tinggi terhadap pembelajaran. Dengan adanya motivasi yang dimiliki maka seorang mahasiswa akan hadir tepat pada waktunya setiap kali ada perkuliahan, mengerjakan tugas yang diberikan dosen dengan sedang hati, memperhatikan dan mencatat setiap kali dosen menerangkan materi perkuliahan, serta mengulang pelajaran setiap hari. Minat akan belajar ini akan semakin tinggi jika motivasi yang dimiliki berasal dari dalam individu itu sendiri, sehinggga walaupun tidak ada orang yang memberikan hadiah atau pujian, namun mereka tetap berminat terhadap proses belajar mengajar di kebidanan tersebut.

\section{KESIMPULAN}

1. Mahasiswa semester III Program Studi D III Kebidanan STIKes Prima Nusantara Bukittinggi tahun 2011 yang memiliki minat belajar tinggi berjumlah 50 orang $(52,1 \%)$ dan yang memiliki minat belajar rendah berjumlah 46 (47,9\%). 
2. Mahasiswa semester III Program Studi D III Kebidanan STIKes Prima Nusantara Bukittinggi tahun 2011 yang memiliki lingkungan belajar baik berjumlah 56 orang $(58,3 \%)$ dan yang memiliki lingkungan belajar kurang baik berjumlah 40 (41,7\%).

3. Mahasiswa semester III Program Studi D III Kebidanan STIKes Prima Nusantara Bukittinggi tahun 2011 yang memiliki motivasi belajar tinggi berjumlah 65 orang $(67,7 \%)$ dan yang memiliki motivasi belajar rendah berjumlah 31 $(32,3 \%)$.

4. Terdapat hubungan bermakna antara lingkungan belajar dengan minat belajar dengan nilai $\mathrm{p}=0,009$ dan $\mathrm{OR}=3,343$

5. Terdapat hubungan bermakna antara motivasi belajar dengan minat belajar dengan nilai $\mathrm{p}=0,004$ dan $\mathrm{OR}=4,17$.

\section{SARAN}

1. Bagi Institusi/ Tempat Penelitian Diharapkan kepada pihak Program Studi D III Kebidanan STIKes Pirma Nusantara Bukittinggi agar dapat memfasilitasi terciptanya lingkungan belajar yang lebih baik untuk menimbulkan minat mahasiswa yang masih rendah guna mencapai prestasi belajar yang lebih tinggi. Dan bagi para dosen untuk lebih berperan dalam memotivasi semangat mahasiswa misalnya memberikan reward kepada mahasiswa berupa beasiswa ataupun tambahan nilai.

2. Bagi Program Studi D IV Bidan Pendidik STIKes Prima Nusantara Bukittinggi Diharapkan bagi Program Studi D IV Bidan Pendidik agar dapat memilih kurikulum yang tepat untuk para calon bidan pendidik yang mana nantinya calon bidan pendidik sebagai dosen dapat memotivasi mahasiswanya dalam belajar.

3. Bagi Peneliti Selanjutya

Diharapkan pada peneliti selanjutnya agar dapat meneliti variabel lain yang dapat mempengaruhi minat belajar seperti bakat dan kecerdasan.

4. Bagi Mahasiswa

Diharapkan pada mahasiswa agar dapat menciptakan lingkungan belajar yang baik bagi dirinya sendiri dan bagi mahasiswa yang memiliki minat belajr tinggi agar dapat membantu temannya yang memiliki minat belajar rendah.

\section{KEPUSTAKAAN ACUAN}

Arikunto, Suharsimi. (2002). Prosedur Penelitian Suatu Pendekatan Praktek Edisi Revisi V. Jakarta : Rineka Cipta. 
Budiarto, Eko. (2002). Metodologi Penelitian Kedokteran. Jakarta: EGC.

Dimyati dan Mudjiono. (2006). Belajar dan Pembelajaran. Jakarta: Rineka Cipta.

Djamarah, S.B. (2008). Psikologi Belajar. Edisi 2. Jakarta: Bumi Aksara.

Fauza, Rahmawani. (2009). Faktor-faktor yang Berhubungan dengan Minat Belajar Mahasiswa Semester IV di Akademi Kebidanan Imelda Medan Tahun Ajaran 2008/ 2009 diakses dari http://www. repository.usu.ac.id

Hastono, S.P. (2001). Analisis Data. Jakarta: Fakultas Kesehatan Masyarakat UI.

Hidayat, A.A. (2007). Metode Penelitian Kebidanan dan Teknik Analisis Data. Jakarta: Salemba Medika.
Notoatmodjo, S. (2005). Metode Penelitian Kesehatan. Jakarta: Rineka Cipta.

Nursalam. (2009). Konsep dan Penerapan Metodologi Penelitian Ilmu Keperawatan Edisi Kedua. Jakarta: Salemba Medika.

Sanjaya, Wina. (2008). Strategi Pembelajaran. Jakarta: Kencana Prenada Media Group. Sardiman A.M. (2011). Interaksi dan Motivasi Belajar Mengajar. Jakarta: Raja Grafindo.

Slameto. (2003). Belajar dan Faktor-Faktor yang Mempengaruhinya. Jakarta: Rineka Cipta.

Syah, M. (2010). Psikologi Belajar. Jakarta: Raja Grafindo Persada. 